\title{
Amycolatopsis halophila sp. nov., a halophilic actinomycete isolated from a salt lake
}

\author{
Shu-Kun Tang, ${ }^{1}$ Yun Wang, ${ }^{2}$ Tong-Wei Guan, ${ }^{3}$ Jae-Chan Lee, ${ }^{4}$ \\ Chang-Jin $\mathrm{Kim}^{4}$ and Wen-Jun $\mathrm{Li}^{1}$
}

Correspondence

Wen-Jun Li

wjli@ynu.edu.cn or

liact@hotmail.com

\begin{abstract}
${ }^{1}$ The Key Laboratory for Microbial Resources of the Ministry of Education, and Laboratory for Conservation and Utilization of Bio-resources, Yunnan Institute of Microbiology, Yunnan University, Kunming 650091, PR China

${ }^{2}$ Xinjiang Institute of Microbiology, Xinjiang Academy of Agricultural Science, Urumqi, Xinjiang 830091, PR China

${ }^{3}$ Key Laboratary of Protection and Utilization of Biological Resources in Tarim Basin of Xinjiang Production \& Construction Corps, Tarim University, Alar, Xinjiang 843300, PR China

${ }^{4}$ Functional Metabolite Research Center KRIBB, 52 Eoeun-dong, Yuseong gu, Daejeon 305-806, Republic of Korea
\end{abstract}

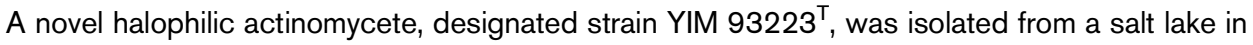
Xinjiang Province, north-west China, and was subjected to a polyphasic taxonomic study. The isolate grew at $25-45{ }^{\circ} \mathrm{C}$, at $\mathrm{pH} 6-8$ and in the presence of $1-15 \%(\mathrm{w} / \mathrm{v}) \mathrm{NaCl}$; no growth was observed in the absence of $\mathrm{NaCl}$. Strain YIM $93223^{\top}$ contained meso-diaminopimelic acid, glutamic acid and alanine as cell-wall amino acids, and glucose and galactose as major whole-cell-wall sugars. Major fatty acids were iso- $\mathrm{C}_{16: 0}, \mathrm{C}_{16: 0}$ and $\mathrm{C}_{16: 1} \omega 7 \mathrm{c} /$ iso- $\mathrm{C}_{15: 0} 2-\mathrm{OH}$. MK-8 $\left(\mathrm{H}_{4}\right)$ was the predominant menaquinone. The genomic DNA G $+\mathrm{C}$ content was $66.1 \mathrm{~mol} \%$. Phylogenetic analysis based on 16S rRNA gene sequences showed that strain YIM 93223 ${ }^{\top}$ belongs to the genus Amycolatopsis. It shared highest $16 \mathrm{~S}$ rRNA gene sequence similarity with Amycolatopsis palatopharyngis $1 \mathrm{BDZ}^{\top}$ (96.6\%) and Amycolatopsis marina Ms392A ${ }^{\top}$ (96.4\%), but lower values (94.5-96.2\%) with the type strains of other recognized species of the genus Amycolatopsis. On the basis of the data from this polyphasic study, strain YIM $93223^{\top}$ is considered to represent a novel species of the genus Amycolatopsis, for which the name Amycolatopsis halophila sp. nov. is proposed. The type strain is YIM $93223^{\top}\left(=\right.$ DSM $45216^{\top}=$ KCTC $\left.19403^{\top}\right)$.
\end{abstract}

The genus Amycolatopsis was first established by Lechevalier et al. (1986) and was classified in the family Pseudonocardiaceae, suborder Pseudonocardineae (Stackebrandt et al., 1997). At the time of writing, it comprises 41 recognized species, most of which have been described in the past few years: Amycolatopsis australiensis (Tan et al., 2006), A. benzoatilytica (Majumdar et al., 2006), A. decaplanina (Wink et al., 2004), A. echigonensis (Ding et al., 2007), A. jejuensis (Lee, 2006), A. halotolerans (Lee, 2006), A. lurida (Lechevalier et al., 1986; Stackebrandt et al., 2004), A. marina (Bian et al., 2009), A. minnesotensis (Lee et al., 2006),

\section{Abbreviation: meso-DAP, meso-diaminopimelic acid.}

The GenBank/EMBL/DDBJ accession number for the 16S rRNA gene sequence of strain YIM 93223 ${ }^{\top}$ is FJ606836.

A scanning electron micrograph of spore chains of strain YIM 93223', chromatograms of hydrolysates of whole-cell sugars and menaquinones of strain YIM $93223^{\top}$ and reference taxa, and a figure showing the polar lipid composition of strain YIM $93223^{\top}$ are available with the online version of this paper.
A. nigrescens (Groth et al., 2007), A. niigatensis (Ding et al., 2007), A. palatopharyngis (Huang et al., 2004), A. plumensis (Saintpierre-Bonaccio et al., 2005), A. regifaucium (Tan et al., 2007), A. rifamycinica (Bala et al., 2004), A. saalfeldensis (Carlsohn et al., 2007), A. taiwanensis (Tseng et al., 2006), A. tucumanensis (Albarracín et al., 2010) and A. ultiminotia (Lee, 2009). These species are non-halophilic actinomycetes, and have been isolated from geographically diverse soils, clinical material, vegetable matter, the wall of a hypogean cave, and ocean sediment.

During a study of halophilic actinomycetes from a soil sample collected from Qijiaojing Lake in Xinjiang Province, north-west China (43 $\left.26^{\prime} 52^{\prime \prime} \mathrm{N} 91^{\circ} 29^{\prime} 18^{\prime \prime} \mathrm{E}\right)$, an Amycolatopsis-like isolate, YIM $93223^{\mathrm{T}}$, was picked after 3 weeks of incubation at $37{ }^{\circ} \mathrm{C}$ on cellulose-casein multi-salt medium (Tang et al., 2008). The strain was maintained on modified International Streptomyces Project (ISP) medium 4 slants containing $5 \%(\mathrm{w} / \mathrm{v}) \mathrm{NaCl}$ at $4{ }^{\circ} \mathrm{C}$, and as a glycerol suspension $\left(20 \%\right.$, v/v) at $-20{ }^{\circ} \mathrm{C}$. Biomass for chemical and molecular studies was obtained 
by cultivation in shaken flasks (about 150 r.p.m.) by using ISP medium 4 without agar [5\%(w/v) $\mathrm{NaCl}, \mathrm{pH} 7.5]$ at $37{ }^{\circ} \mathrm{C}$ for 2 weeks.

Cultural characteristics were determined after incubation for 3-4 weeks according to Shirling \& Gottlieb (1966). All growth media were supplemented with $5 \%(\mathrm{w} / \mathrm{v}) \mathrm{NaCl}$. The colours of substrate and aerial mycelia and any soluble pigments produced were determined by comparison with chips from the ISCC-NBS colour charts (Kelly, 1964). Good growth was observed on inorganic salts-starch agar, oatmeal agar and potato agar, moderate growth was observed on Czapek's agar, and weak growth on glycerol/ asparagine agar and yeast extract-malt extract; no growth was observed on nutrient agar. The aerial mycelium was white and the substrate mycelium was white-yellow. No soluble pigments were produced. Morphological characteristics of strain YIM $93223^{\mathrm{T}}$ were observed by light microscopy (model BH 2; Olympus) and scanning electron microscopy (JSM5600LV; JEOL) after 21 days of growth on ISP medium 4 containing agar and $5 \%(\mathrm{w} / \mathrm{v}) \mathrm{NaCl}$. The morphological characteristics of strain YIM $93223^{\mathrm{T}}$ were typical for the genus Amycolatopsis (Lechevalier et al., 1986; Stackebrandt et al., 2004). The substrate mycelium was well developed and fragmented into squarish, rod-like elements. The aerial mycelium differentiated into long chains of spore-like structures at maturity (see Supplementary Fig. S1 in IJSEM Online).

Growth temperature was tested at $5-55{ }^{\circ} \mathrm{C}$ on ISP medium 4 containing $5 \%(\mathrm{w} / \mathrm{v}) \mathrm{NaCl}$, at intervals of $5{ }^{\circ} \mathrm{C}$. For $\mathrm{NaCl}$ tolerance experiments, ISP medium 4 was used as the basal medium, and salt concentrations ranging from 0 to $20 \%$ $(\mathrm{w} / \mathrm{v})$ at intervals of $1 \%$ were tested. The $\mathrm{pH}$ range for growth was investigated between 4.0 and 10.0 at intervals of $1 \mathrm{pH}$ unit, by using the buffer system: $\mathrm{pH} 4.0-5.0,0.1 \mathrm{M}$ citric acid/0.1 M sodium citrate; $\mathrm{pH} 6.0-8.0,0.1 \mathrm{M}$ $\mathrm{KH}_{2} \mathrm{PO}_{4} / 0.1 \mathrm{M} \mathrm{NaOH} ;$ pH 9.0-10.0, $0.1 \mathrm{M} \mathrm{NaHCO}_{3} /$ $0.1 \mathrm{M} \mathrm{Na}_{2} \mathrm{CO}_{3}$. Media and procedures used for determination of physiological features and carbon source utilization were those described by Williams et al. (1989). Antibiotic susceptibility was determined according to the method of Williams (1967). Strain YIM $93223^{\mathrm{T}}$ was able to grow at $25-45{ }^{\circ} \mathrm{C}$, at $\mathrm{pH} 6.0-8.0$ and in the presence of $1-15 \% \mathrm{NaCl}$, but no growth occurred in the absence of $\mathrm{NaCl}$, showing that strain YIM $93223^{\mathrm{T}}$ was a halophilic actinomycete. Strain YIM $93223^{\mathrm{T}}$ could be distinguished from recognized species of the genus Amycolatopsis based on a combination of phenotypic properties (Table 1). The detailed physiological and biochemical characteristics of strain YIM $93223^{\mathrm{T}}$ are given in the species description below.

A. marina $\mathrm{Ms} 392 \mathrm{~A}^{\mathrm{T}}$ and A. palatopharyngis $1 \mathrm{BDZ} \mathrm{Z}^{\mathrm{T}}$ were used as reference strains for studies of whole-cell sugars and menaquinones. A purified cell-wall preparation was obtained and was hydrolysed as described by Schleifer \& Kandler (1972). Amino acids in cell-wall hydrolysates were analysed by precolumn derivatization with $o$-phthalaldehyde by HPLC (Tang et al., 2009a). Whole-cell sugars were detected by precolumn derivatization with 1-phenyl-3methyl-5-pyrazolone by HPLC (Tang et al., 2009b). Mycolic acids were checked by the acid methanolysis method of Minnikin et al. (1980). Polar lipids were

Table 1. Differential phenotypic characteristics between strain YIM $93223^{\top}$ and its nearest phylogenetic neighbours in the genus Amycolatopsis

Strains: 1, YIM $93223^{\mathrm{T}}$ (data from the present study); 2, A. marina Ms392A $\mathrm{A}^{\mathrm{T}}$ (Bian et al., 2009); 3, A. palatopharyngis $1 \mathrm{BDZ}^{\mathrm{T}}$ (Huang et al., 2004). + , Positive; w, weakly positive; -, negative.

\begin{tabular}{|c|c|c|c|}
\hline Characteristic & 1 & 2 & 3 \\
\hline $\mathrm{NaCl}$ range $(\%, w / v)$ & $1-15$ & $0.5-12$ & $0-10$ \\
\hline $\mathrm{pH}$ range & $6.0-8.0$ & $6.0-9.0$ & $6.0-10.0$ \\
\hline Temperature range $\left({ }^{\circ} \mathrm{C}\right)$ & $25-45$ & $10-45$ & $10-40$ \\
\hline Catalase & - & + & - \\
\hline Nitrate reduction & - & - & + \\
\hline \multicolumn{4}{|l|}{ Decomposition of: } \\
\hline L-Lysine & - & - & + \\
\hline Starch & - & $\mathrm{W}$ & - \\
\hline Urea & - & - & $\mathrm{W}$ \\
\hline \multicolumn{4}{|l|}{ Utilization as sole carbon source } \\
\hline L-Arabinose & - & - & $\mathrm{w}$ \\
\hline L-Rhamnose & + & + & - \\
\hline Maltose & - & + & - \\
\hline Raffinose & + & - & $\mathrm{w}$ \\
\hline Major fatty acids $(>10 \%)$ & $\begin{array}{l}\text { iso- } \mathrm{C}_{16: 0}(28.9 \%), \\
\mathrm{C}_{16: 0}(18.6 \%), \mathrm{C}_{16: 1} \omega 7 c l \\
\text { iso- } \mathrm{C}_{15: 0} 2-\mathrm{OH}(12.3 \%)\end{array}$ & $\begin{array}{l}\text { iso- } \mathrm{C}_{16: 0}(40.4 \%), \\
\text { iso- } \mathrm{C}_{16: 0} 2-\mathrm{OH}(11.4 \%)\end{array}$ & $\begin{array}{l}\text { iso- } \mathrm{C}_{16: 0}(50.3 \%), \\
\mathrm{C}_{16: 0}(21.7 \%), \\
\text { anteiso- } \mathrm{C}_{17: 0}(12.4 \%)\end{array}$ \\
\hline DNA G $+C$ content $(\mathrm{mol} \%)$ & 66.1 & 70.1 & 65.8 \\
\hline
\end{tabular}


extracted and examined by two-dimensional TLC and were identified by using the procedures described by Minnikin et al. (1984). Menaquinones were isolated according to Minnikin et al. (1984) and were separated by HPLC (Kroppenstedt, 1982) with Amycolatopsis orientalis subsp. orientalis CGMCC $4.1214^{\mathrm{T}}$ and Streptomyces griseus subsp. griseus ATCC $23345^{\mathrm{T}}$ as reference strains; identification was confirmed by atmospheric pressure photoionization (APPI) (+)-LC-MS (Tang et al., 2008). For fatty acid analysis, cells of strain YIM $93223^{\mathrm{T}}$ were cultured on trypticase soy agar (Difco) containing $5 \% \mathrm{NaCl}$ at $37{ }^{\circ} \mathrm{C}$ for 7 days. Analysis was performed as described by Sasser (1990) by using the Microbial Identification System (MIDI). Strain YIM $93223^{\mathrm{T}}$ contained meso-diaminopimelic acid (meso-DAP), glutamic acid and alanine as cellwall amino acids, and glucose and galactose as major whole-cell sugars (minor amounts of mannose and ribose were also detected, and trace amounts or no arabinose) (Table 2 and Supplementary Fig. S2). Phospholipids detected were diphosphatidylglycerol, phosphatidylethanolamine, hydroxy-phosphatidylethanolamine, phosphatidylinositol, phosphatidylinositolmannosides and an unknown phospholipid (Supplementary Fig. S3). The predominant menaquinone was MK-8 $\left(\mathrm{H}_{4}\right)(87.3 \%)$; $\mathrm{MK}-8\left(\mathrm{H}_{6}\right)(5.2 \%)$ and MK-9 $\left(\mathrm{H}_{4}\right)(7.5 \%)$ were detected as minor components (Supplementary Figs S4 and S5). Strain YIM $93223^{\mathrm{T}}$ had a cellular fatty acid profile that contained major amounts of straight, saturated and branched components and minor

Table 2. Menaquinone compositions and hydrolysates of whole-cell sugars of strain YIM $93223^{\top}$ and closely related species of the genus Amycolatopsis

Strains: 1, YIM $93223^{\mathrm{T}} ; 2$, A. marina $\mathrm{Ms} 392 \mathrm{~A}^{\mathrm{T}} ; 3$, A. palatopharyngis $1 \mathrm{BDZ}^{\mathrm{T}}$. All data are from the present study. tr, Trace; -, not present.

\begin{tabular}{|c|c|c|c|}
\hline Characteristic & 1 & 2 & 3 \\
\hline \multicolumn{4}{|c|}{ Menaquinone composition (\%) } \\
\hline $\mathrm{MK}-8\left(\mathrm{H}_{4}\right)$ & 88.4 & 8.2 & 8.7 \\
\hline MK-8 $\left(\mathrm{H}_{6}\right)$ & 5.7 & 3.5 & - \\
\hline MK-9 $\left(\mathrm{H}_{2}\right)$ & - & - & 2.5 \\
\hline MK-9 $\left(\mathrm{H}_{4}\right)$ & 5.9 & 84.1 & 85.4 \\
\hline MK-9 $\left(\mathrm{H}_{6}\right)$ & - & 1.9 & 1.4 \\
\hline MK-10 $\left(\mathrm{H}_{4}\right)$ & - & 2.3 & 2.1 \\
\hline \multicolumn{4}{|l|}{ Whole-cell sugars (\%) } \\
\hline Mannose & 7.3 & 9.9 & 17.7 \\
\hline Ribose & 6.4 & - & - \\
\hline Unknown sugar A & - & 4.6 & 1.4 \\
\hline Rhamnose & 1.7 & 2.0 & - \\
\hline Glucosamine & 1.4 & 24.9 & 5.8 \\
\hline Unknown sugar B & - & - & 3.7 \\
\hline Unknown sugar $\mathrm{C}$ & 11.0 & - & - \\
\hline Glucose & 36.0 & 2.6 & 15.3 \\
\hline Unknown sugar D & - & 6.9 & 10.8 \\
\hline Galactose & 36.2 & 39.4 & 32.0 \\
\hline Arabinose & $\operatorname{tr}$ & 9.7 & 13.3 \\
\hline
\end{tabular}

straight-chain, unsaturated and methyl components. Fatty acids present at $>1 \%$ were: $\mathrm{C}_{14: 0}(2.6 \%)$, iso- $\mathrm{C}_{15: 0}$ (1.4\%), $\mathrm{C}_{15: 0}(2.4 \%)$, iso- $\mathrm{C}_{16: 0} \mathrm{G}(1.6 \%)$, iso- $\mathrm{C}_{16: 0}$ (28.9\%), $\mathrm{C}_{16: 0}$ (18.6\%), $\mathrm{C}_{16: 0} 10$-methyl $(2.1 \%)$, iso$\mathrm{C}_{17: 0}(1.6 \%)$, anteiso- $\mathrm{C}_{17: 0}(3.1 \%), \mathrm{C}_{17: 1} \omega 8 c(4.7 \%)$, $\mathrm{C}_{17: 1} \omega 6 c(1.8 \%), \mathrm{C}_{17: 0}(4.9 \%), \mathrm{C}_{18: 1} \omega 9 c(5.5 \%), \mathrm{C}_{18: 0}$ $(4.1 \%)$ and $\mathrm{C}_{16: 1} \omega 7 c /$ iso- $\mathrm{C}_{15: 0} 2-\mathrm{OH}(12.3 \%)$.

Extraction of genomic DNA and PCR amplification of the $16 \mathrm{~S}$ rRNA gene were performed as described by Li et al. (2007). The 16S rRNA gene was amplified by PCR by using eubacterial primers 27F and 1492R (DeLong, 1992) and PCR products were purified by using a Sangon PCR purification kit. Multiple alignments with sequences of closely related species of the genus Amycolatopsis and calculations of levels of sequence similarity were carried out by using the EzTaxon server 2.0 (Chun et al., 2007). Phylogenetic analyses were performed by using three treemaking algorithms, namely the neighbour-joining (Saitou \& Nei, 1987), maximum-likelihood (Felsenstein, 1981) and maximum-parsimony (Fitch, 1971) methods. A phylogenetic tree was constructed with the neighbour-joining method from $K_{\text {nuc }}$ values (Kimura, 1980) by using MEGA version 4.0 (Tamura et al., 2007). The topology of the phylogenetic tree was evaluated by the bootstrap resampling method of Felsenstein (1985) based on 1000 replicates. For determination of the $\mathrm{G}+\mathrm{C}$ content of the genomic DNA of strain YIM $93223^{\mathrm{T}}$, DNA was prepared according to the method of Marmur (1961). The G+C content was determined by reversed-phase HPLC of nucleosides according to Mesbah et al. (1989).

The results of $16 \mathrm{~S}$ rRNA gene sequence comparisons clearly demonstrated that strain YIM $93223^{\mathrm{T}}$ was a member of the genus Amycolatopsis. In the phylogenetic tree based on the neighbour-joining algorithm, strain YIM $93223^{\mathrm{T}}$ formed a monophyletic clade with $A$. palatopharyngis $1 \mathrm{BDZ}^{\mathrm{T}}$ and $A$. marina Ms $392 \mathrm{~A}^{\mathrm{T}}$, supported by a bootstrap value of $51 \%$ (Fig. 1). The topology of the phylogenetic tree built with the maximum-likelihood method was similar to that of the neighbour-joining tree but was different from that of the maximum-parsimony tree. In the phylogenetic tree based on the maximum-parsimony algorithm, strain YIM $93223^{\mathrm{T}}$ formed a monophyletic clade with $A$. taiwanensis $0345 \mathrm{M}-7^{\mathrm{T}}$ (data not shown). Levels of $16 \mathrm{~S}$ rRNA gene sequence similarity between strain YIM $93223^{\mathrm{T}}$ and its closest neighbours, $A$. palatopharyngis $1 \mathrm{BDZ}^{\mathrm{T}}$ and A. marina $\mathrm{Ms} 392 \mathrm{~A}^{\mathrm{T}}$, were 96.6 and $96.4 \%$, respectively, while similarities with the type strains of other species of the genus Amycolatopsis were 94.5-96.2\%. The G+C content of the DNA of strain YIM $93223^{\mathrm{T}}$ was $66.1 \mathrm{~mol} \%$.

It is evident from the phenotypic and phylogenetic data (Fig. 1 and Fig. S1) that strain YIM $93223^{\mathrm{T}}$ represents a novel species of the genus Amycolatopsis. Although strain YIM $93223^{\mathrm{T}}$ is similar to A. palatopharyngis $1 \mathrm{BDZ}^{\mathrm{T}}$ and A. marina $\mathrm{Ms} 392 \mathrm{~A}^{\mathrm{T}}$ in colony colour (white to yellow) and shares the same subclade in the phylogenetic tree, it differs in some morphological and physiological properties 


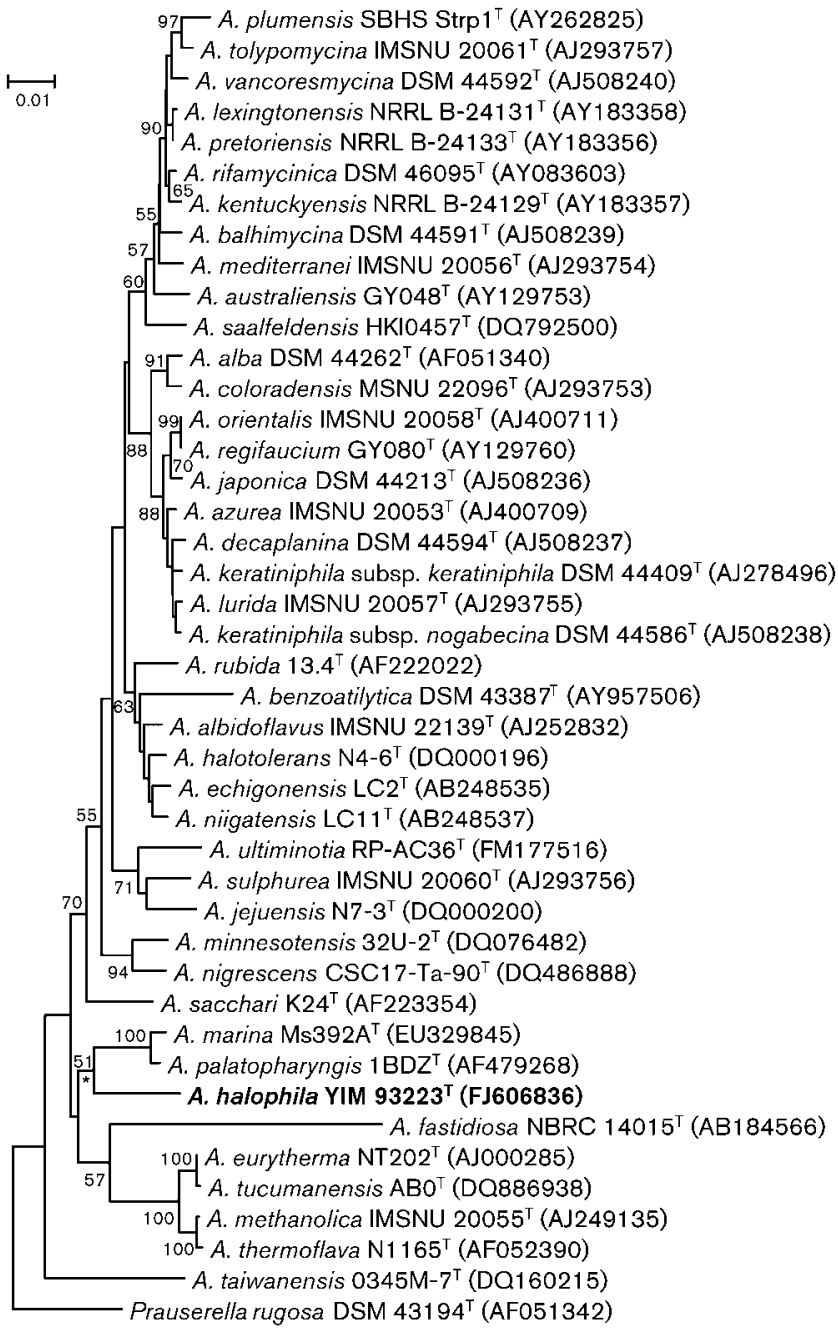

Fig. 1. Neighbour-joining phylogenetic dendrogram obtained by distance matrix analysis of 16S rRNA gene sequences, showing the position of strain YIM $93223^{\top}$ among species of the genus Amycolatopsis. Asterisks indicate branches of the tree that were also found by using the maximum-likelihood algorithm. Numbers at nodes indicate levels of bootstrap support (\%) based on a neighbour-joining analysis of 1000 resampled datasets (only values $>50 \%$ are shown). The sequence of Prauserella rugosa DSM $43194^{\top}$ was used as an outgroup. Bar, 0.01 substitutions per nucleotide position.

(Table 1), i.e. strain YIM $93223^{\mathrm{T}}$ can grow at $15 \% \mathrm{NaCl}$ and no growth is observed in the absence of $\mathrm{NaCl}$. Strain YIM $93223^{\mathrm{T}}$ differed from $A$. palatopharyngis $1 \mathrm{BDZ}^{\mathrm{T}}$ and A. marina $\mathrm{Ms} 392 \mathrm{~A}^{\mathrm{T}}$ in a number of chemotaxonomic properties (Tables 1 and 2). Strain YIM $93223^{\mathrm{T}}$ contained glucose and galactose as major whole-cell sugars, no or only trace arabinose in the cell wall, $\mathrm{MK}-8\left(\mathrm{H}_{4}\right)$ as the predominant menaquinone, and iso- $\mathrm{C}_{16: 0}, \mathrm{C}_{16: 0}$ and $\mathrm{C}_{16: 1} \omega 7 c /$ iso- $\mathrm{C}_{15: 0} 2-\mathrm{OH}$ as major fatty acids; by contrast, A. palatopharyngis $1 \mathrm{BDZ}^{\mathrm{T}}$ and A. marina $\mathrm{Ms}^{2} 92 \mathrm{~A}^{\mathrm{T}}$ contained galactose, arabinose, mannose and glucose or glucosamine as major whole-cell sugars, $\mathrm{MK}-9\left(\mathrm{H}_{4}\right)$ as the predominant menaquinone, and iso- $\mathrm{C}_{16: 0}$ and iso- $\mathrm{C}_{16: 0}$ 2- $\mathrm{OH}$, or iso- $\mathrm{C}_{16: 0}, \mathrm{C}_{16: 0}$, and anteiso- $\mathrm{C}_{17: 0}$ as major fatty acids.

On the basis of the phenotypic, chemotaxonomic and phylogenetic data presented, strain YIM $93223^{\mathrm{T}}$ should be placed in the genus Amycolatopsis as the type strain of a novel species, for which we propose the name Amycolatopsis halophila sp. nov.

\section{Emended description of the genus Amycolatopsis Lechevalier et al. 1986}

The description is as given by Lechavalier et al. with the following additions. The genus encompasses alkaliphilic, mesophilic, thermophilic, pathogenic and halophilic species. Can tolerate up to $15 \% \mathrm{NaCl}$. Whole-cell-wall sugars contain no or only trace arabinose. Predominant menaquinone is $\mathrm{MK}-8\left(\mathrm{H}_{4}\right)$ or $\mathrm{MK}-9\left(\mathrm{H}_{4}\right)$.

\section{Description of Amycolatopsis halophila sp. nov.}

Amycolatopsis halophila (ha.lo.phi'la. Gr. n. hals halos salt; Gr. adj. philos loving; N.L. fem. adj. halophila salt-loving, referring to the ability of the type strain to grow at high $\mathrm{NaCl}$ concentrations).

Aerobic, Gram-positive, halophilic, filamentous actinomycete. Substrate mycelia are well developed and fragment into squarish, rod-like elements. Aerial mycelia differentiate into long chains of spore-like structure at maturity. Growth occurs at $25-45^{\circ} \mathrm{C}$, at $\mathrm{pH} 6.0-8.0$ and in the presence of $1-15 \% \mathrm{NaCl}$. Optimal growth occurs at $37{ }^{\circ} \mathrm{C}$, $\mathrm{pH} 7.0$ and $5 \% \mathrm{NaCl}$; no growth occurs in the absence of $\mathrm{NaCl}$. Tweens 20, 40 and 60 are degraded, but aesculin, casein, starch, cellulose, chitin, Tween 80 and urea are not. Positive for gelatin liquefaction, but negative for nitrate reduction, milk peptonization and coagulation, $\mathrm{H}_{2} \mathrm{~S}$, and melanin production. Utilizes D-galactose, raffinose, L-rhamnose, trehalose, inositol, xylitol, erythritol, sodium acetate, glycerol and trisodium citrate as sole carbon source, but not D-glucose, L-arabinose, cellobiose, D-ribose, D-fructose, D-mannose, D-xylose, maltose, lactose, dulcitol, mannitol, sorbitol or sodium propionate. Utilizes Lthreonine, L-arginine, glycine, L-serine, L-histidine, Lproline, L-tyrosine, alanine, L-methionine, hypoxanthine, $\mathrm{L}$-asparagine and xanthine as sole nitrogen source, but not L-lysine, L-phenylalanine or adenine. In the API ZYM system, positive for alkaline phosphatase, esterase (C4), esterase lipase (C8), lipase (C14), leucine arylamidase, valine arylamidase, cystine arylamidase, trypsin, $\alpha$-glucosidase, $\beta$-glucosidase and $N$-acetyl- $\beta$-glucosaminidase, but negative for acid phosphatase, $\alpha$-chymotrypsin, naphthol-AS-BIphosphohydrolase, $\alpha$-galactosidase, $\beta$-galactosidase, $\beta$-glucuronidase, $\alpha$-mannosidase and $\beta$-fucosidase. Susceptible (per disc) to ciprofloxacin $(5 \mu \mathrm{g})$, amoxicillin $(10 \mu \mathrm{g})$, novobiocin $(5 \mu \mathrm{g})$, tetracycline $(30 \mu \mathrm{g})$ and erythromycin $(15 \mu \mathrm{g})$, but resistant to netilmicin $(10 \mu \mathrm{g})$, norfloxacin 
$(10 \mu \mathrm{g})$, penicillin $(10 \mu \mathrm{g})$, ampicillin $(10 \mu \mathrm{g})$, tobramycin $(10 \mu \mathrm{g})$, sulfamethoxazole $(23.75 \mu \mathrm{g})$, amikacin $(30 \mu \mathrm{g})$ and clindamycin. Contains meso-DAP, glutamic acid and alanine as cell-wall diamino acids, and glucose and galactose as major whole-cell sugars. The major fatty acids are iso- $\mathrm{C}_{16: 0}, \mathrm{C}_{16: 0}$ and $\mathrm{C}_{16: 1} \omega 7 c /$ iso- $\mathrm{C}_{15: 0}$ 2-OH. MK- $8\left(\mathrm{H}_{4}\right)$ is the predominant menaquinone. Mycolic acids are not detected. Phospholipids present are diphosphatidylglycerol, phosphatidylethanolamine, hydroxy-phosphatidylethanolamine, phosphatidylinositol, phosphatidylinositolmannosides and an unknown phospholipid. The DNA $\mathrm{G}+\mathrm{C}$ content of the type strain is $66.1 \mathrm{~mol} \%$.

The type strain, YIM $93223^{\mathrm{T}}\left(=\mathrm{DSM} 45216^{\mathrm{T}}=\mathrm{KCTC}\right.$ $19403^{\mathrm{T}}$ ), was isolated from a salt lake in Xinjiang Province, north-west China.

\section{Acknowledgements}

This research was supported by the National Basic Research Program of China (no. 2004CB719601), the National Natural Science Foundation of China (nos 30600001, 30860002, 30870005), the 973 Pre-research Program of China (2008CB417214), the Ministry of Science of Technology, PR China (2006DFA33550), Youth Technological Innovation Foundation of Xinjiang Academy of Agricultural Science (no. 2007Q07) and Korea Foundation for International Cooperation of Science \& Technology through a grant provided by the Korean Ministry of Education, Science and Technology in Global Partnership Program.

\section{References}

Albarracin, V. H., Alonso-Vega, P., Trujillo, M. E., Amoroso, M. J. \& Abate, C. M. (2010). Amycolatopsis tucumanensis sp. nov., a copperresistant actinobacterium isolated from polluted sediments. Int J Syst Evol Microbiol 60, 397-401.

Bala, S., Khanna, R., Dadhwal, M., Prabagaran, S. R., Shivaji, S., Cullum, J. \& Lal, R. (2004). Reclassification of Amycolatopsis mediterranei DSM 46095 as Amycolatopsis rifamycinica sp. nov. Int J Syst Evol Microbiol 54, 1145-1149.

Bian, J., Li, Y., Wang, J., Song, F. H., Liu, M., Dai, H. Q., Ren, B., Gao, H., Hu, X. \& other authors (2009). Amycolatopsis marina sp. nov., an actinomycete isolated from an ocean sediment. Int J Syst Evol Microbiol 59, 477-481.

Carlsohn, M. R., Groth, I., Tan, G. Y. A., Schütze, B., Saluz, H. P., Munder, T., Yang, J., Wink, J. \& Goodfellow, M. (2007). Amycolatopsis saalfeldensis sp. nov., a novel actinomycete isolated from a medieval alum slate mine. Int J Syst Evol Microbiol 57, 1640-1646.

Chun, J., Lee, J.-H., Jung, Y., Kim, M., Kim, S., Kim, B. K. \& Lim, Y. W. (2007). EzTaxon: a web-based tool for the identification of prokaryotes based on $16 \mathrm{~S}$ ribosomal RNA gene sequences. Int J Syst Evol Microbiol 57, 2259-2261.

DeLong, E. F. (1992). Archaea in coastal marine environments. Proc Natl Acad Sci U S A 89, 5685-5689.

Ding, L., Hirose, T. \& Yokota, A. (2007). Amycolatopsis echigonensis sp. nov. and Amycolatopsis niigatensis sp. nov., novel actinomycetes isolated from a filtration substrate. Int J Syst Evol Microbiol 57, 17471751.

Felsenstein, J. (1981). Evolutionary trees from DNA sequences: a maximum likelihood approach. J Mol Evol 17, 368-376.
Felsenstein, J. (1985). Confidence limits on phylogenies: an approach using the bootstrap. Evolution 39, 783-791.

Fitch, W. M. (1971). Toward defining the course of evolution: minimum change for a specific tree topology. Syst Zool 20, 406416.

Groth, I., Tan, G. Y. A., González, J. M., Laiz, L., Carlsohn, M. R., Schütze, B., Wink, J. \& Goodfellow, M. (2007). Amycolatopsis nigrescens sp. nov., an actinomycete isolated from a Roman catacomb. Int J Syst Evol Microbiol 57, 513-519.

Huang, Y., Paściak, M., Liu, Z., Xie, Q. \& Gamian, A. (2004). Amycolatopsis palatopharyngis sp. nov., a potentially pathogenic actinomycete isolated from a human clinical source. Int J Syst Evol Microbiol 54, 359-363.

Kelly, K. L. (1964). Inter-Society Color Council - National Bureau of Standards Color Name Charts Illustrated with Centroid Colors. Washington, DC: US Government Printing Office.

Kimura, M. (1980). A simple method for estimating evolutionary rates of base substitutions through comparative studies of nucleotide sequence. J Mol Evol 16, 111-120.

Kroppenstedt, R. M. (1982). Separation of bacterial menaquinones by HPLC using reverse phase (RP18) and a silver loaded ion exchanger as stationary phases. J Liq Chromatogr 5, 2359-2367.

Lechevalier, M. P., Prauser, H., Labeda, D. P. \& Ruan, J.-S. (1986). Two new genera of nocardioform actinomycetes: Amycolata gen. nov. and Amycolatopsis gen. nov. Int J Syst Bacteriol 36, 29-37.

Lee, S. D. (2006). Amycolatopsis jejuensis sp. nov. and Amycolatopsis halotolerans sp. nov., novel actinomycetes isolated from a natural cave. Int J Syst Evol Microbiol 56, 549-553.

Lee, S. D. (2009). Amycolatopsis ultiminotia sp. nov., isolated from rhizosphere soil, and emended description of the genus Amycolatopsis. Int J Syst Evol Microbiol 59, 1401-1404.

Lee, S. D., Kinkel, L. L. \& Samac, D. A. (2006). Amycolatopsis minnesotensis sp. nov., isolated from a prairie soil. Int J Syst Evol Microbiol 56, 265-269.

Li, W. J., Xu, P., Schumann, P., Zhang, Y. Q., Pukall, R., Xu, L. H., Stackebrandt, E. \& Jiang, C. L. (2007). Georgenia ruanii sp. nov., a novel actinobacterium isolated from forest soil in Yunnan (China) and emended description of the genus Georgenia. Int J Syst Evol Microbiol 57, 1424-1428.

Majumdar, S., Prabhagaran, S. R., Shivaji, S. \& Lal, R. (2006). Reclassification of Amycolatopsis orientalis DSM 43387 as Amycolatopsis benzoatilytica sp. nov. Int J Syst Evol Microbiol 56, 199-204.

Marmur, J. (1961). A procedure for the isolation of deoxyribonucleic acid from microorganisms. J Mol Biol 3, 208-218.

Mesbah, M., Premachandran, U. \& Whitman, W. B. (1989). Precise measurement of the $\mathrm{G}+\mathrm{C}$ content of deoxyribonucleic acid by highperformance liquid chromatography. Int J Syst Bacteriol 39, 159167.

Minnikin, D. E., Hutchinson, I. G., Caldicott, A. B. \& Goodfellow, M. (1980). Thin-layer chromatography of methanolysates of mycolic acid-containing bacteria. J Chromatogr A 188, 221-233.

Minnikin, D. E., O'Donnell, A. G., Goodfellow, M., Alderson, G., Athalye, M., Schaal, A. \& Parlett, J. H. (1984). An integrated procedure for the extraction of bacterial isoprenoid quinones and polar lipids. J Microbiol Methods 2, 233-241.

Saintpierre-Bonaccio, D., Amir, H., Pineau, R., Tan, G. Y. A. \& Goodfellow, M. (2005). Amycolatopsis plumensis sp. nov., a novel bioactive actinomycete isolated from a New-Caledonian brown hypermagnesian ultramafic soil. Int J Syst Evol Microbiol 55, 20572061. 
Saitou, N. \& Nei, M. (1987). The neighbor-joining method: a new method for reconstructing phylogenetic trees. Mol Biol Evol 4, 406425.

Sasser, M. (1990). Identification of bacteria by gas chromatography of cellular fatty acids. USFCC Newsl 20, 16.

Schleifer, K. H. \& Kandler, O. (1972). Peptidoglycan types of bacterial cell walls and their taxonomic implications. Bacteriol Rev 36, 407-477.

Shirling, E. B. \& Gottlieb, D. (1966). Methods for characterization of Streptomyces species. Int J Syst Bacteriol 16, 313-340.

Stackebrandt, E., Rainey, F. A. \& Ward-Rainey, N. L. (1997). Proposal for a new hierarchic classification system, Actinobacteria classis nov. Int J Syst Bacteriol 47, 479-491.

Stackebrandt, E., Kroppenstedt, R. M., Wink, J. \& Schumann, P. (2004). Reclassification of Amycolatopsis orientalis subsp. lurida Lechevalier et al. 1986 as Amycolatopsis lurida sp. nov., comb. nov. Int J Syst Evol Microbiol 54, 267-268.

Tamura, K., Dudley, J., Nei, M. \& Kumar, S. (2007). MEGA4: molecular evolutionary genetics analysis (MEGA) software version 4.0. Mol Biol Evol 24, 1596-1599.

Tan, G. Y. A., Robinson, S., Lacey, E. \& Goodfellow, M. (2006). Amycolatopsis australiensis sp. nov., an actinomycete isolated from arid soils. Int J Syst Evol Microbiol 56, 2297-2301.

Tan, G. Y. A., Robinson, S., Lacey, E., Brown, R., Kim, W. \& Goodfellow, M. (2007). Amycolatopsis regifaucium sp. nov., a novel actinomycete that produces kigamicins. Int J Syst Evol Microbiol 57, 2562-2567.

Tang, S. K., Tian, X. P., Zhi, X. Y., Cai, M., Wu, J. Y., Yang, L. L., Li-Hua Xu, L. H. \& Li, W. J. (2008). Haloactinospora alba gen. nov., sp. nov., a halophilic filamentous actinomycete of the family Nocardiopsaceae. Int J Syst Evol Microbiol 58, 2075-2080.

Tang, S. K., Wang, Y., Chen, Y., Lou, K., Cao, L. L., Xu, L. H. \& Li, W.-J. (2009a). Zhihengliuella alba sp. nov., and emended description of the genus Zhihengliuella. Int J Syst Evol Microbiol 59, 2025-2032.

Tang, S. K., Wang, Y., Lou, K., Mao, P. H., Xu, L. H., Jiang, C. L., Kim, C. J. \& Li, W. J. (2009b). Kocuria halotolerans sp. nov., an actinobacterium isolated from a saline soil in China. Int J Syst Evol Microbiol 59, 13161320.

Tseng, M., Yang, S. F., Li, W. J. \& Jiang, C. L. (2006). Amycolatopsis taiwanensis sp. nov., from soil. Int J Syst Evol Microbiol 56, 1811-1815.

Williams, S. T. (1967). Sensitivity of streptomycetes to antibiotics as a taxonomic character. J Gen Microbiol 46, 151-160.

Williams, S. T., Goodfellow, M. \& Alderson, G. (1989). Genus Streptomyces Waksman and Henrici 1943, 339 ${ }^{\mathrm{AL}}$. In Bergey's Manual of Systematic Bacteriology, vol. 4, pp. 2463-2468. Edited by S. T. Williams, M. E. Sharpe \& J. G. Holt. Baltimore: Williams \& Wilkins.

Wink, J., Gandhi, J., Kroppenstedt, R. M., Seibert, G., Sträubler, B., Schumann, P. \& Stackebrandt, E. (2004). Amycolatopsis decaplanina sp. nov., a novel member of the genus with unusual morphology. Int $J$ Syst Evol Microbiol 54, 235-239. 